ВІСНИК

ОДЕСЬКОГО НАЦІОНАЛЬНОГО

МОРСЬКОГО УНІВЕРСИТЕТУ
HERALD

OF THE ODESSA NATIONAL

MARITIME UNIVERSITY № 1 (64), 2021

УДК 620.9:697.34

DOI 10.47049/2226-1893-2021-1-140-148

\title{
ДЕЯКІ ПИТАННЯ ЗБЕРЕЖЕННЯ ЕНЕРГОРЕСУРСІВ ПРИ ТЕПЛОПОСТАЧАННІ У БУДИНКАХ
}

К.Ю. Федорова

к.т.н., доцент кафедри «Цивільна інженерія та архітектура» ooolinesshop@gmail.com

Одеський національний морський університет, Одеса, Украӥна

Анотація. У статті розглядаються проблеми, пов'язані з енергозбереженням та енергоефективністю енергоресурсів. Дуже тривожним є факт, пов'язаний з дефіцитом основних енергоресурсів, зростанням вартісного їх видобутку, а також з глобальними екологічними проблемами.

У статті вирішуються проблеми економї енергоресурсів при опаленні приміщень. Розроблено функиіональну схему системи автоматичного регулювання опалення для окремо взятої квартири багатоквартирного будинку з автономним опаленням.

Ключові слова: енергоресурси, енергоефективність, енергозбереження, екологічні проблеми, функиіональна схема, автоматичне регулювання, опалення, «розумний дім», теплопостачання.

УДК 620.9:697.34

DOI 10.47049/2226-1893-2021-1-140-148

\section{НЕКОТОРЫЕ ВОПРОСЫ СОХРАНЕНИЯ ЭНЕРГОРЕСУРСОВ ПРИ ТЕПЛОСНАБЖЕНИИ В ДОМАХ}

\section{Е.Ю. Федорова}

к.т.н., доцент кафедры «Гражданская инженерия и архитектура» ooolinesshop@gmail.com

Одесский национальный морской університет, Одесса, Украина

Аннотация. B статье рассматриваются проблемы, связанные с энергосбережением и энергоэффективностью энергоресурсов. Очень тревожным является факт, связанный с дефицитом основных энергоресурсов, увеличением стоимости их добычи, а также $c$ глобальными экологическими проблемами.

В статье решаются проблемы экономии энергоресурсов при отоплении зданий. Разработана функииональная схема системы автоматического регулирования отопления для отдельно взятой квартиры многоквартирного дома с автономным отоплением.

Ключевые слова: энергоресурсы, энергоэффективность, энергосбережение, экологические проблемы, функциональная схема, автоматическое регулирование, отопление, «умный дом», теплоснабжение.

(С Федорова К.Ю., 2021 
UDC 620.9:697.34

DOI 10.47049/2226-1893-2021-1-140-148

\title{
CERTAIN ISSUES OF ENERGY CONSERVATION IN HEAT SUPPLY IN HOUSES
}

\author{
E.Yu. Fedorova \\ Ph.D., Docent of the «Civil engineering and architecture» \\ ooolinesshop@gmail.com \\ Odessa National Maritime University, Odessa, Ukraine
}

\begin{abstract}
The article deals with the issues related to energy saving and energy efficiency of energy resources. The fact that there is a shortage of basic energy resources, an increase in the cost of their production, as well as global environmental problems is very worrying. The issues of economy of energy resources at heating of the room are solved, the functional scheme of system of automatic regulation of heating for the separately taken apartment of the apartment house with autonomous heating is developed in the article

Keywords: energy resources, energy efficiency, energy saving, enviromental problems, functional schemes, automatic regulation, heating, "smart home», heat supply.
\end{abstract}

Природні енергоресурси $є$ важливою умовою економічного розвитку будь-якої країни. Проте, лише невелика кількість країн видобувають нафту та газ у тій кількості, що не лише перекривають свої потреби, але й випускають цей товар на світовий ринок.

Морським транспортом перевозиться значна частина вантажів по усьому світу. Особливо це стосується наливних вантажів, таких як сира нафта, нафтопродукти, скраплений природний газ. Морські вантажоперевезення - це економічно вигідний спосіб доставлення вантажів на великі відстані.

Порівняно $з$ іншими видами перевезень вантажів на значні відстані морські відрізняються наступними перевагами:

1) вартість перевезення вантажів морем нижча, ніж доставлення вантажів багатьма іншими способами;

2) універсальність. Таким чином транспортуються різні товари: нафта, нафтопродукти, скраплений газ;

3) висока швидкість завантажувально-розвантажувальних робіт.

Сьогодні міжнародні вантажоперевезення (особливо, нафти, газу) користуються великим попитом. Однак, за будь-якого економічно вигідного доставлення вартість енергоресурсів у країні зростає за рахунок витрат на перевезення. Зменшити вартість енергоресурсів можна за рахунок зменшення обсягів споживання населенням країни. 
ВІСНИК

ОДЕСЬКОГО НАЦІОНАЛЬНОГО

МОРСЬКОГО УНІВЕРСИТЕТУ № 1 (64), 2021
HERALD

OF THE ODESSA NATIONAL

MARITIME UNIVERSITY № 1 (64), 2021

Для розуміння проблем, пов'язаних з поняттям збереження енергоресурсів, визначимо значення енергоефективності та енергозберігання.

Енергоефективність - це комплекс організаційних, економічних і технологічних заходів, спрямованих на підвищення значення раціонального використання енергетичних ресурсів у виробничій, побутовій та науково-технічній сферах. Говорячи більш простою мовою, енергоефективність - це ефективне використання енергії, а отже й скорочення комунальних витрат. Слова енергоефективність і енергозбереження часто згадуються разом. Хоча існує взаємозв'язок, все ж це різні речі. Ефективність означає отримання необхідного результату 3 використанням меншої кількості енергії. Зберігання, однак, означає споживання меншої кількості енергії або зовсім відмова від іiї використання. Ефективність часто призводить до заощадження енергії, але не навпаки.

На даний час енергозбереження $є$ одним 3 пріоритетних завдань держави. Це пов'язано з дефіцитом основних енергоресурсів, зростанням вартістю їх видобутку, а також з глобальними екологічними проблемами. Відомо, що велика частина енергоресурсів в нашій країні виробляється 3 органічного палива (90 \%). До ядерного палива підірвано довіру громадськості через ризик аварій з глобальними наслідками і проблеми захоронення радіоактивних відходів. Великі гідроелектростанції порушують екологічні пропорції (затоплення територій, зволоження клімату, збиток рибному господарству і т.д.). Відновлювальні енергоресурси (сонячна, вітрова, геотермальна і т.д.) поки мають обмежені можливості при промисловому використанні. Однак, їх використання можна віднести до порівняно екологічно чистих технологій отримання енергії.

Останні події у США, пов'язані $з$ відмовою роботи джерел відновлювальних енергоресурсів при зниженні температур, призвели до екологічної катастрофи. Це пов'язано з тим, що роботи у цьому напрямі не закінчені. Їх слід продовжити й проводити для оцінки роботи цих джерел у максимальних кліматичних показаннях кожного регіону. Отже, нині слід займатися впритул економною втратою енергоресурсів, здобутих для використання в регіоні.

Економія енергії - це ефективне використання енергоресурсів за рахунок застосування інноваційних рішень, які здійснено технічно, обгрунтовано економічно, прийнятно з екологічної та соціальної точок зору, не змінюють звичного способу життя.

В Україні прийнято низку законів, які стосуються енергозбереження, складено план розвитку енергетики країни на найближчі 15 років, спрямований на збільшення частки використання альтернативних джерел енергії, але, здебільшого, енергоефективних технологій та підвищення іiі енергоефективності взагалі. В усіх сферах діяльності в нашій державі прагнуть зменшити енергоспоживання й витрати енергії (в тому числі тепла). 
Система теплопостачання країни досить велика й громіздка. Вона потребує колосальних обсягів енергії, й при цьому відбуваються не менш колосальні витрати тепла та енергії. Тобто, іншими словами, можна казати, що основна частина енергії витрачається на опалення будинків. I це досить логічно, можна уявити, скільки необхідно витратити вугілля та газу для того, щоб опалювати, приміром, 16-ти поверховий будинок, в якому розташовано не менше 136 квартир площею 50-70 м² кожна. Такі значні витрати енергії пов'язані з великими втратами тепла за неконтрольованих витрат у кожній квартирі енергоресурсів, що витрачаються на опалення.

Ось чому тему даної роботи можна вважати сучасною та актуальною.

Відповідно до прийнятих законів в Україні здійснюється державне регулювання у сфері підвищення енергоефективності та енергозбереження. В цьому законі було уведено поняття «клас енергоефективності». Клас енергоефективності кваліфікує енергетичну ефективність обладнання під час його експлуатації. Перший і найбільш ефективний метод пов'язаний 3 підвищенням теплового опору огороджувальних конструкцій, а саме:

- облицювання зовнішніх стін, технічного поверху, покрівлі, перекриття над підвалом теплоізоляційними плитами - зниження тепловтрат до $40 \%$;

- усунення містків холоду у стінах і в приляганнях віконних рам (ефект 2-3\%);

- влаштування в огорожах/фасадах прошарків, вентильованих повітрям, що відводиться з приміщень;

- застосування теплозахисних штукатурок;

- зменшення площі скління до нормативних значень;

- засклення балконів і лоджій (ефект 10-12 \%);

- заміна/застосування сучасних вікон 3 багатокамерними склопакетами і палітурками 3 підвищеним тепловим опором;

- застосування вікон 3 відведенням повітря 3 приміщення через міжскловий простір (ефект 4-5\%);

- встановлення провітрювачів та застосування мікровентиляції;

- застосування тепловідбивного/сонцезахисного скла у вікнах i при склінні лоджій та балконів;

- скління фасадів для акумулювання сонячного випромінювання (ефект від 7 до $40 \%$ );

- застосування зовнішнього скління має різні характеристики накопичення тепла влітку і взимку;

- встановлення додаткових тамбурів при вхідних дверях під'їздів і в квартирах;

- регулярне інформування жителів про стан теплозахисту будівлі та заходи щодо економії тепла. 
Існують способи підвищення енергоефективності системи опалення, які пов'язані з наступними роботами:

- заміна чугунних радіаторів на більш ефективні алюмінієві;

- застосування систем поквартирного обліку тепла (теплолічильники, індикатори тепла, температури);

- реалізація заходів щодо розрахунку за тепло за кількістю встановлених секцій і місця розташування опалювачів;

- встановлення тепловідбивних екранів за радіаторами опалення (ефект 1-3\%);

- сезонне промивання опалювальної системи;

- встановлення фільтрів мережевої води на вході і виході опалювальної системи;

- використання неметалевих трубопроводів;

- теплоізоляція труб у підвальному приміщенні будинку; опалення;

- перехід при ремонті до схеми індивідуального поквартирного

- регулярне інформування жителів про стан системи опалення, втрати і нераціональне витрачання тепла і заходи щодо підвищення ефективності роботи системи опалення.

Нині усі ці заходи з підвищення енергоефективності враховуються на етапі планування та проектування багатоквартирних житлових будинків. У житловому фонді старих будівель ці заходи реалізувати практично неможливо, тому що пов'язані вони зі значними грошовими витратами. Отже, необхідно розглядати окрім відомих методів, нові, сучасні, які не пов'язані з великими капітальними вкладеннями.

Зупинимося на розгляді сучасного, зразкового контролю та управлінні інженерними системами будинку, які називають системою «розумний дім».

Усі пристрої системи «розумний дім» - панелі оператора, пульти дистанційного керування, комп'ютери, планшети та мобільні телефони об'єднуються в інформаційну мережу для обміну даними між вузлами системи. Принциповим моментом є віддалений контроль та управління системою «розумний дім» за допомогою Інтернету.

Усього кілька років тому система «розумний дім» вважалася ознакою заможності власника житлового об'єкта з огляду на високу вартість як самого обладнання, так і програмного забезпечення. Все змінилося з розвитком технологій автоматизації, каналів зв'язку, а також мобільних пристроїв.

Системи «розумний дім» 3 одного боку 3 кожним роком стають все більш доступними і 3 іншого - встановлюють нові критерії комфортної життєдіяльності. Власники квартир і заміських будинків тепер оцінюють не лише функціональність і зручність даних систем, але й їх економічність, практичність та надійність. Тому сучасні системи 
«розумний дім» проектуються так, щоб їх у першу чергу відрізняла ергономічність, зручність і проста експлуатація.

Системи життєзабезпечення (СЖЗ) у будинках - це група інженерно-технологічних систем і мереж, які дозволяють будь-якій людині існувати у сприятливих умовах і вирішують завдання, спрямовані на підтримку прийнятного рівня життєдіяльності. У звичайних умовах повсякденної діяльності людина знаходиться у замкненому просторі майже цілодобово. Тому в приміщеннях повинно бути створено прийнятне середовище для досягнення нормального рівня існування мешканців і роботи трудящих. Дані умови доцільно підтримувати протягом усього циклу перебування людей всередині будівлі, надаючи необхідні ресурси, що споживаються людиною, і видаляючи залишки та відходи життєдіяльності.

СЖЗ у будь-якій будівлі представлені набором зі складових їх інженерних систем та мереж. Залежно від типу приміщень визначаються i засоби життєзабезпечення людини для них. Але для будь-яких внутрішніх місць, які відвідуються людьми, можуть бути виділені наступні класи СЖЗ:

- типові (основні, класичні);

- допоміжні (додаткові).

Головне призначення систем у складі СЖЗ - це забезпечення у будинках змінних режимів, які є придатними в життєдіяльності мешканців, зазвичай, для відпочинку і для працюючих співробітників, здебільшого, для праці. Людський організм не може функціонувати без таких ресурсів, як повітря, вода, світло, тепло, тож необхідні інженерні підсистеми і мережі повинні забезпечувати відповідні умови життєдіяльності всередині приміщень, які потрібно постачати електроенергію, здійснювати повітрообмін, контролювати наявність води і виконувати інші завдання в цілодобовому режимі.

У даній роботі розроблено функціональну схему системи автоматичного регулювання опалення для окремо взятої квартири багатоквартирного будинку з автономним опаленням. Сьогодні дослідження, які проводилися протягом останніх 10 років, показали, що будинки з автономними джерелами тепла набагато ефективніші та економічніші (через зменшення втрат тепла при транспортуванні), ніж будинки з центральним опаленням.

Функціональну схему системи автоматичного регулювання опалення наведено на рис.

Система опалення працює наступним чином. Тут передбачено $N$ задавачів температури (ЗД) кожної кімнати для забезпечення нормального функціонування приміщення, яке несе своє функціональне навантаження (приміром, дитяча кімната, вітальня, кабінет і т.д.), де комфортна температура має бути різною. Усього показано $N$ приміщень у квартирі. Від задавача 
температури $(3 Д 1, \ldots$, ЗД $N$ ) електричний сигнал, що пропорційний заданій температурі, надходить на один вхід ПП - пристрою порівняння. На другий вхід цього ж пристрою ПП надходить сигнал від давача температури (Д1...Д $\left.{ }_{N}\right)$ даної кімнати.

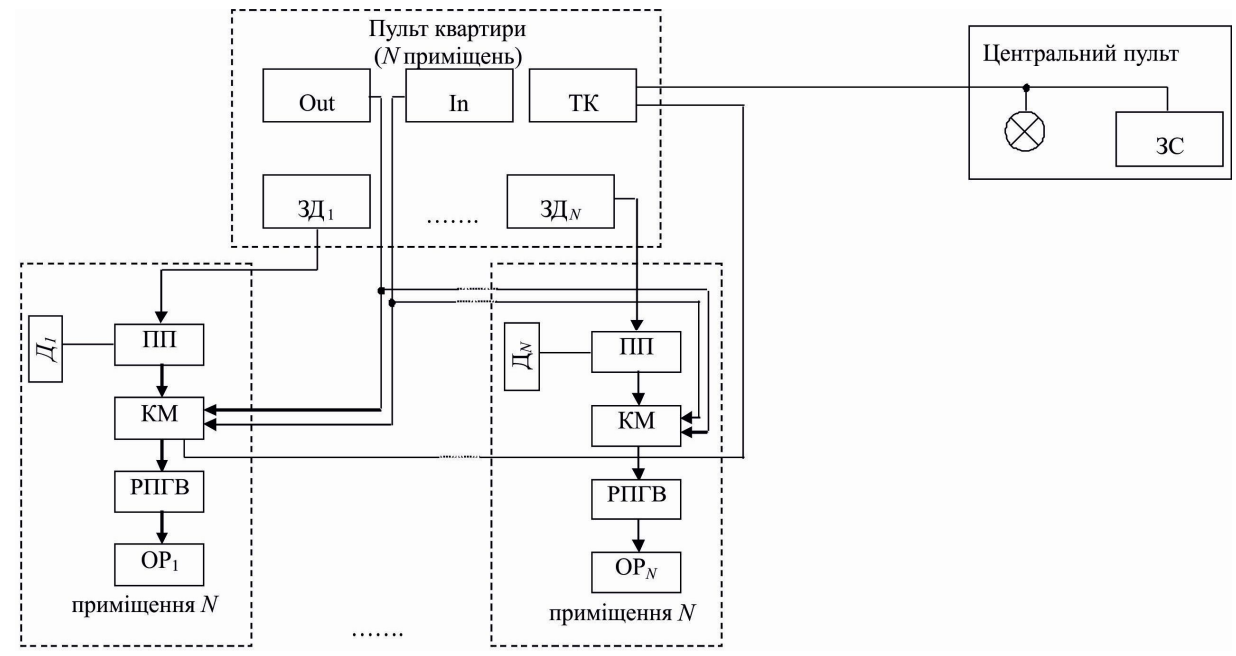

Рис. Функціональна схема

автоматичного регулювання системи опалення

Пристрій порівняння (ПП) порівнює отримані два значення: від задавача $t$ i від давача $t$. Якщо при цьому встановлена на задавачі температура більша, аніж показує давач, виробляється сигнал «Збільшити подачу». За оберненого значення, коли давач температури Д показує температуру, більшу, аніж встановлено на аналогічному задавачі (ЗД), виробляється сигнал протилежної полярності, що відповідає встановленню «Зменшити подачу».

3 виходу пристрою порівняння ПП сигнал надходить на керуючий модуль (КМ), який за допомогою автоматичного регулятора подачі гарячої води (РПГВ) або закриває вхідний клапан опалювального радіатора ОР, при цьому температура знижується, або відкриває вхідний клапан РПГВ, завдяки чому температура у кімнаті в кінцевому підсумку збільшується.

У даній розробці припускається увести можливість проводити регулювання в квартирі залежно від знаходження або відсутності в ній мешканців. Цей процес $є$ додатковою економією енергоресурсів. На пульт квартири уводяться дві кнопки: Out - якщо 3 квартири виходять люди та In - якщо люди повертаються. За ручного натискання кнопки Out подається сигнал на керуючий модуль. За допомогою цього сигналу блокується управління 3 пристрою порівняння і в квартирі встановлюється мінімально можлива температура на ОР. Друга кнопка In виконує 
наступну роботу. При натисканні останньої знімається блокування управління від пристрою порівняння. Керуючий модуль КМ через РПГВ встановлює задану подачу, і температура в кімнаті дуже швидко відновлюється до заданої.

Слід зазначити, що наявність задавача температури у кожній кімнаті дозволяє регулювати температуру у денний та нічний час, що обов'язково призводить до підвищення енергоефективності пропонованої розробки.

Якщо температура води, яка надходить 3 котельної, недостатня для підтримки заданої температури, існує тривожна кнопка ТК, яка сигналізує на пульт даної квартири й подає сигнал на центральний пульт, де загоряється лампа й надходить звуковий сигнал. При цьому необхідно регулювати подачу більш гарячої води з котельної.

Для управління і налаштування будинку 3 офісу, машини і т.д. програма системи «розумний дім» дозволяє за допомогою електронної пошти передавати необхідні команди. Для цього основна програма поділяється на два незалежних модуля, один з яких знаходиться у будинку і чекає команд. Інший же знаходиться на робочому комп'ютері користувача.

Більшість систем «розумний дім» працюють в автоматичному режимі і не потребують будь-якого втручання людини. Однак завжди присутня інформація, яку потрібно повідомити користувачеві або яка йому була б в принципі корисною: температура на вулиці, прогноз погоди, зображення з камер спостереження, звіти про роботу автоматичних алгоритмів і т.д. Крім того, в низці випадків необхідно мати можливість також дистанційно керувати пристроєм.

Таким чином, схематично «розумний дім» складається ніби 3 трьох основних елементів: центральний процесор, керовані ним виконавчі механізми та інтерфейсні пристрої, за допомогою яких можна спілкуватися 3 центральним процесором.

Центральний процесор - це сервер. Як сервер можна використовувати все що завгодно, від суперкомп'ютера 3 гелієвим охолодженням до роутера і мікроконтролера.

Висновки. У висновку хотілося б додати, що зменшення енергоспоживання дозволяє одночасно поліпшити фізичний стан повітряної атмосфери. Викиди газів від спалювання органічних i неорганічних джерел тепла викликає парниковий ефект в атмосфері Землі, в результаті якого останнім часом спостерігається підвищена кількість природних потрясінь. Стрімкий приріст парникових газів багато в чому залежить від теплоспоживання будівель. За оцінками вчених на їх утримання витрачається до половини згенерованої енергії. За розрахунками фахівців Міжнародного енергетичного агентства (MEA) уведення енергозберігаючих технологій може призвести до скорочення цих викидів до 45 \%. 
ВІСНИК

ОДЕСЬКОГО НАЦІОНАЛЬНОГО

МОРСЬКОГО УНІВЕРСИТЕТУ
HERALD

OF THE ODESSA NATIONAL

MARITIME UNIVERSITY

№ 1 (64), 2021

\section{СПИСОК ЛІТЕРАТУРИ}

1. Орлов В.О. Водопостачання та водовідведення: Підручник / В.О. Орлов, Я.А. Тугай, А.М. Орлова. -К.: Знання, 2011. 360 с.

2. ДБН 13.2.5-64: 2012 Внутрішній водонапір та каналізація. Ч. I: Проектування.

3. Мацієвська О.О. Водопостачання і водовідведення / О.О. Мацієвська. - Л.: Львівська політехніка, 2015. - 144 с.

4. Краснянський М.Н. Енергозабезпечення / М.Н. Краснянський. Л.: Львівська політехніка, 2018. - 136 c.

5. Задорожна І.П. Основи енергоефективності: Навч.-метод. посібник / І.П. Задорожна. - Л., 2011. - 82 c.

\section{REFERENCES}

1. Orlov, V.O. Vodopostachannya ta vodovidvedennya: Pidruchnik/ V.O. Orlov, Ya.A. Tugaj, A.M. Orlova. - K.: Znannya, 2011. 360 s.

2. DBN 13.2.5-64: 2012. Vnutrishnij vodo napir ta kanalizaciya. Ch. I: Proektuvannya.

3. Maciyevska, O.O. Vodopostachannya $i$ vodovidvedennya / O.O. Maciyevska. - L.: Lvivska politehnika, 2015. - 144 s.

4. Krasnyanskij, M.N. Energozabezpechennya/M.N. Krasnyanskij. L.: Lvivska politehnika, 2018. - 136 s.

5. Zadorozhna, I.P. Osnovi energoefektivnosti: Navch.-metod. posibn. / I.P. Zadorozhna. - L., 2011. - 82 s.

Стаття надійшла до редакиії 22.03.2021

Посилання на статтю: Федорова К.Ю. Деякі питання збереження енергоресурсів при теплопостачанні у будинках. // Вісник Одеського національного морського університету: Зб. наук. праць, 2021. № 1 (64). С. 140-148. DOI 10.47049/ 2226-1893-2021-1-140-148.

Article received 22.03.2021

Reference a JournalArtic: Fedorova E.Yu. Certain issues of energy conservation in heat supply in houses // Herald of the Odessa National Maritime University. 2021. 1(64), 140-148. DOI 10.47049/2226-1893-2021-1-140-148. 